\title{
An Evidence-Based Framework for Reducing Occupational Stress and Burnout in Pakistani Universities
}

\author{
Naima Akhtar Malik ${ }^{1 *}$, Kaj Björkqvist ${ }^{2}$, \\ 12 Department of Developmental Psychology \\ Åbo Akademi University, Finland \\ nmalik@abo.fi* \\ kbjorkqvist@abo.fi \\ *Corresponding Author
}

https://doi.org/10.24191/ajue.v17i1.12623

Received: 1 November 2020

Accepted:20 December 2020

Date Published Online: 8 March 2021

Published: 8 March 2021

\begin{abstract}
The aim of the study was to design a framework for university administrations to provide guideline for the effective management of the issues of occupational stress and burnout among university teachers in Pakistan. A total of 320 university teachers participated in the study. Of the respondents, $144(45 \%)$ were female, and $176(55 \%)$ were male. The questionnaire was especially constructed for the study and it comprised six subscales. The results showed that there was no significant gender difference between the scores of the respondents except on one scale. The results show that university teachers are not satisfied with the efforts made by university administrations to deal with problems of occupational stress and burnout. In the light of the results, a framework has been designed for university administrations in Pakistan.
\end{abstract}

Keywords: Burnout, Framework, Pakistan, Occupational stress, University teachers, University administration

\section{Introduction}

Occupational stress is a well-researched global phenomenon, and teaching has been identified as a stressful profession (Hartney, 2008). However, most of the studies have focused on schoolteachers, and fewer have explicitly focused on university teachers (Watts \& Robertson, 2011). As Kinman and Wray (2013) point out, while a certain level of stress is expected in any profession, the stress in adult education is of societal concern. Occupational stress is an emerging problem also in developing countries (Malik, Björkqvist, \& Österman, 2017a). Not enough is known about the extent of the problem in developing countries due to scarceness of research, a fact which hampers the awareness about the issue (Kortum, Leka, \& Cox, 2010).

Lack of capacity to cope with occupational stress affects the efficiency of university teaching. Stress may lead to burnout (Steinhardt, Jaggars, Faulk, \& Gloria, 2011; Agatha \& Chan, 2020) which, in turn, hampers academic effectiveness. Usually, teacher training does not prepare teachers to deal with occupational stress, and it comes as a surprise when they start on their career (Kerr, Breen, Delaney, Kelly, \& Miller, 2011). Stress management training could likely aid in decreasing teacher stress and enhancing the quality of university education. However, there is no evidence that such professional development approaches have been incorporated into the teacher training programme or continuing professional development curricula for university teachers to any remarkable extent (Hartney, 2020). Not enough has been done to provide teachers with skills and sufficient knowledge to help them survive and flourish in this challenging profession (Hartney, 2020). 
Pakistan, as a developing country, faces several challenges, and major improvements are needed in different sectors; higher education is one of them. University teachers are facing various stressors in the university work environment that instigates burnout (Faisal, Noor, \& Khair, 2019; Khan, Din, \& Anwar, 2019; Yusoff, \& Khan, 2013). Furthermore, the Pakistan Higher Education Commission (HEC) has changed the policy, emphasising the development of skills, competence, and innovations. It further has linked the recruitments and promotions of the university teachers with research publications. Thus, university teachers are experiencing more stress due to high demands and high-performance expectations based on the education commission policies (Bhatti, Hashmi, Raza, Shaikh, \& Shafiq, 2011; Raza, 2012; Khan, Rasli, Khan, Yasir, \& Malik, 2014). Lack of proper counselling and training intensifies the severity of occupational stress, as teachers are not capable of coping with too many problematic situations (Jepson \& Forrest, 2006).

Developing stress management skills would facilitate university teachers to reduce and prevent burnout symptoms (Zhao \& Ding, 2020). According to Khan, Din, and Anwar (2019), the teachers working in universities with a high level of stress and burnout showed lower job satisfaction, poor organisational commitment, and high turnover intentions. Such teachers are inclined to leave or switch their jobs. Moreover, they experience physical and psychological health issues which adversely affect their performance (Khan et al., 2019). Research suggests that university teachers should manage burnout at the individual level while the administration should handle the problem at the institutional level. In order to enable teachers to handle the issue of occupational stress and burnout, proper training should be provided to them (Houtman, Jettinghof, \& Cedillo, 2007). It will help them to understand the gravity of the issue, and also provide them with the opportunity to learn coping skills and knowledge about how to deal with this contemporary challenge in academia. Such training should be a critical part of their continuous professional development (Arshad, 2019; Khan et al., 2019).

Though it is impossible to eliminate stress entirely, individuals can learn to manage it (Richardson \& Rothstein, 2008). Many institutions have introduced stress management training programmes to try to reduce employees stress levels. These attempts indicate that stress management skills can be taught to reduce stress levels and ease symptoms of strain (Richardson \& Rothstein, 2008). A stress management programme is any activity which can be initiated by an institution that emphasises to reduce work-related stressors or supporting individuals to reduce the adverse effects of these stressors (Ivancevich, Matteson, Freedman, \& Phillips, 1990). There are stress management programmes which focus on the buffers in the stress process, and they try to increase employee support systems so that they may have more resources to draw upon when experiencing high stress. Some programmes focus on developing a more inclusive environment at the workplace, enabling employees to take part in the decision-making so that they take the stress as a challenge to be met instead of a burden to carry (Heaney \& Van Ryn, 1990). Institutional practices that successfully prevent teachers' burnout are usually those that allow them to have some control over their environmental challenges (Mohammed, Suleyman, \& Taylan, 2020). Hence, it is obvious that there are many choices for policymakers to design stress management programmes. One can choose to reduce stressors, to change employees' perceptions of their environment, to decrease employees' reactivity to a stressor, or to improve the work environment and the relationships between colleagues, as a buffer against stress and burnout. Therefore, the focus can be the employees' attitudes and/or organisational policies and priorities.

Not many attempts have been made in developing countries to design policy frameworks to reduce occupational stress and burnout among teachers in the higher education sector. Therefore, the current study intends to suggest a policy framework for university teachers in the light of empirical data from Pakistan, for emerging economies in general, but specifically for Pakistan. The objective is to guide university administrations in designing and implementing a policy dealing with work stress and burnout. It will provide help, support, and guide university teachers in not only understanding but preparing them for this widespread issue. The societal implication of this research is to facilitate the development of a healthy university work environment.

\section{Literature Review}

The term "stress" is frequently used to explain an unpleasant internal state, usually initiated by external factors or "stressors;" e.g., occupational stress is caused by a demanding work environment (Hartney, 2020). Occupational stress is a feeling of psychological strain due to work stressors (Gershon, 
Barocas, Canton, Li, \& Vlahov, 2009). The psychological strain comprises the occurrence of distasteful emotions, such as frustration, anger, anxiety, tension, and depression, due to work-related factors (Kyriacou \& Sutcliffe, 1977). Occupational stress has harmful effects on wellbeing, health, efficiency, and the cost-effectiveness of the workforce.

Studies within several fields of research, for instance, psychology, higher education, and medicine have identified occupational stress as a leading cause of health issues (Malik \& Björkqvist, 2018; Takahashi, 2016). A prolonged stressful situation at work may contribute to various symptoms including aggression, anxiety, sleeping problems, depression, and burnout, (Gershon et al., 2009; Williams \& Cooper, 1998), mental strain, job dissatisfaction (Winefield, Gillespie, Stough, Dua, Hapuarachchi, \& Boyd, 2003), hypertension, psychological disorders (Wang, Lesage, Schmitz, \& Drapeau, 2008), suicidal trends (Olkinuora, Asp, Juntunen, Kauttu, Strid, \& Äärimaa, 1990), fatigue, headaches, muscle pain, back and neck pain, gastrointestinal problems (Nixon, Mazzola, Bauer, Krueger, \& Spector, 2011), diabetes (Wellen, \& Hotamisligil, 2005) and heart disease (Brotman, Golden, \& Wittstein, 2007; Dimsdale, 2008).

In addition to these symptoms, teachers subjected to stress are more likely to experience a lower level of job satisfaction in comparison with other occupations (Collie, Shapka, \& Perry, 2012; Jepson \& Forrest, 2006), a higher level of burnout (Yu, Wang, Zhai, Dai, \& Yang, 2015), a lower level of selfefficacy (Skaalvik \& Skaalvik, 2017), and weak job commitment (Jepson \& Forrest, 2006). Female university teachers report more stress than male university teachers (Malik, Björkqvist \& Österman, 2017a; Slišković, \& Seršić, 2011). The European Foundation for the Improvement of Living and Working Conditions stated that stress affects one-third of the European working population (Giga, Cooper, \& Faragher, 2003).

Teachers' occupational stress has become at the focus of education policymakers and educators around the world (Donovan, 2018). Mostert, Nell, Mostert, and Rothmann (2008) found that stress is not only affecting individuals' performance in higher education institutions but also adding cost and producing undesirable results. They further elaborated that because of stress, university employees display offensive behaviour and emotions, and poor physical and mental health. Research works suggest that an increase in absenteeism (Bermejo Toro, \& Prieto Ursúa, 2014; Malik, Björkqvist, \& Österman, 2017b), mental health, and musculoskeletal health are associated with a stressful work environment (Malik \& Björkqvist, 2018). Workplace stress may lead to mental health issues, intensified sickness absence, and resignations (Naghieh, Montgomery, Bonell, Thompson, \& Aber, 2015). Moreover, teachers' mental health issues are influencing the quality of education (Narayanappa, Manjunath, Kulkarni, 2016; Navinés, Martin-Santos, Olive, \& Valdes, 2016) because mental health has a significant impact on teaching skills, which in turn affects the academic success of the students.

The constant pressure confronted by teachers in higher education institutions is expected to have an adverse effect on the quality of work-life and produce burnout (Johnsrud, 2002). Burnout has been explained as a stress syndrome that involves a decrease in physical and emotional vigour (Schaufeli \& Buunk, 2003). Besides, the burnout syndrome may well be considered as the logical outcome when continuous stressful demands go beyond the individual's resources (Malik, Björkqvist, \& Österman, 2017b). Teachers who are not aware or unable to manage their stress often experience burnout (Tucker, 2010). University teachers are more at risk than other types of teachers to suffer from burnout (Navarro, Mas, \& Jimenez, 2010; Otero-Lopez, Marino, \& Bolano, 2008; Watts \& Robertson, 2011).

Efforts to tackle the issues of stress and burnout could potentially help individual teachers to reverse the phenomenon (Hartney, 2020). This does not mean that the stress due to teaching will be eradicated, but rather, teachers will become more effective in countering and adjusting to stressors at work, without affecting the quality of their work and without becoming burnt out. To work efficiently, teachers should be taught some necessary skills in coping with the stressors that are inherent in the teaching profession (Hartney, 2020).

Many fruitful intervention programmes started by improving the participants' awareness and knowledge about stress and burnout. Sessions to create awareness were organised in a non-threatening environment, offering participants with the latest evidence-based information about the nature, causes, and symptoms of stress and burnout, helping participants to identify the sources of stress (Brown \& Uehara, 1999). Likewise, Bunce and West (1996) found that individuals could be empowered through various stress-management activities. Employees may gain both short and long-term effects of such 
training sessions, e.g. it may enhance peer support, decrease somatic disorders, improve feelings of personal accomplishment, reduce role ambiguity and work pressure, and improve job satisfaction (Brown, \& Uehara, 1999). Ganster, Mayes, Sime, and Tharp (1982) highlighted the importance of specialised trainers in conducting the interventions programme.

It is required to evaluate the stress levels among teachers and support and prepare them to deal with such issues. The demanding nature of teaching occupation should neither be ignored by the administration, nor by those who are responsible for developing teachers training programmes and their continuing professional development programs. The reduction of teacher stress and burnout consequently improves positive mental health (Malik, \& Björkqvist, 2018), performance, teaching quality, and effectiveness of the teachers. Research has shown that professional development has positive effects among teachers in both developing and developed countries (Correnti, 2007; Desimone, Porter, Garet, Yoon, \& Birman, 2002; Garet, Porter, Desimone, Birman, \& Yoon, 2001).

\section{Method}

\subsection{Sample}

The sample comprised of university teachers from twenty-five conveniently sampled public sector universities in Pakistan. To collect the data, the official email addresses of permanent/full-time teachers, lecturers, and professors were obtained from the university websites. More than 3500 email were sent out, with a link to an online survey which could be filled in only once. In total, 320 university teachers responded to the online survey; of the respondents, 144 (45\%) were female, and 176 (55\%) were male. It is difficult to estimate the exact response rate as it is not possible to authenticate the valid number of active email addresses. Some of the emails bounced back to the sender. The majority of the respondents were between 32 and 40 years old. The mean age was 38 years (SD 7.4) for females, and 40 years $(S D$ 7.0) for males; there was no age difference between the sexes.

\subsection{Instrument}

A questionnaire was specifically developed for this study to measure the existing situation regarding workplace policies and programmes to deal with the issue of occupational stress and burnout among Pakistani universities teachers. The questionnaire comprised six subscales: Policy and Prevention, Creating Awareness, Organisational strategies, Promote Good Working Relationships, Support recovery at work, Evaluation of Policy/Action Plan. The responses options for all scales were given on a five-point scale $(0=$ strongly disagree, $1=$ disagree, $2=$ neutral, $3=$ agree, $4=$ strongly agree). A pilot study was conducted by sending in the survey questionnaire on the email addresses of the university teachers in Pakistan. The reliability of the scales was estimated with Cronbach's alpha. The reliability scores of the scales varied between .80 and .95 . The same method was then used for the final data collection. All the teachers were informed about the aims of the study, and confidentiality was guaranteed. Sample items of the six scales, and their reliability scores (Cronbach's $\alpha$ ), are presented in Table 1.

Table 1. Items and Cronbach's Alphas of the Scales in the Study (Overall Cronbach's Alpha .95)

\begin{tabular}{l}
\hline Policy and Prevention ( 7 items, $\boldsymbol{\alpha}=\mathbf{. 9 3}$ ) \\
The administration: \\
\hline Tries to identify work stressors in the work environment \\
Gather evidence of signs and symptoms of stress and burnout among university \\
teachers on a periodic basis \\
Design policy and action plan to reduce stress and burnout among teachers \\
Ensure the implementation of Policies/ Plan related to work stress and burnout \\
Evaluate mechanisms designed to ensure plan implementation and are the desired \\
results achieved \\
Assess the financial cost and advantages of the plan before implementation \\
Ensure that the teachers are satisfied with the arrangements and the ways of \\
implementation
\end{tabular}




\section{Creating Awareness ( 2 items, $\alpha=.80$ )}

The administration

Provides written and verbal information about job stress and burnout

Organises workshops, training sessions, and seminars to promote awareness among university teachers about the nature, causes and consequences of work stress and burnout

\section{Promote Good Working Relationships ( 4 items, $\alpha=.83$ )}

The administration:

Promote social relationships to improve communication

Carry out recreational activities to improve social relationships, communication, and cohesion among the teaching staff

Emphasises good working relationships with colleagues

Provide support to the staff whenever needed

Organisational Strategies ( 11 items, $\alpha=.95$ )

The administration

Consider workplace factors causing stress among university teachers

Promote collective actions to recover from stress and burnout

Promote teacher's participation in decision making

Promote teacher's involvement in the stress management process

Plans regular meetings to discuss the problems faced by the teachers and finding solutions

Create a trustworthy work environment to promote dialogue and knowledge sharing

Carry out training sessions to control stress and burnout

Promote peer social support and cooperation among colleagues

Improve intra-organisational communication, including feedback, encouraging

openness or developing a shared vision

Rules and regulation regarding development opportunities, evaluation, and promotion criteria are clearly described

Knowledge sharing among colleagues and head of the department in an open and informal environment

\section{Support Recovery at Work ( 2 items, $\alpha=.90$ )}

The administration:

Provide training in coping skills for managing stress and burnout for the teaching staff

Provision of mentors at work and professional help of the psychologist or occupational health services/ professionals are available to the teachers to get help whenever needed.

Evaluation of Policy/Action Plan ( 6 items, $\alpha=.93$ )

The administration:

Analyse whether the implementation process has been successful in producing the desired effects.

Assess how far the goals have been achieved?

Assess whether the action plan has unexpected effects?

Assess the financial costs and benefits of the action plan?

Assess how far the people involved are satisfied with their new arrangements or ways of working?

Asked the teachers to analyse the new situation and compare the new situations with the previous one. 


\section{4. $\quad$ Results}

Pearson's correlation coefficients between the scales of the study are presented in Table 2. All correlations were significant at the .001-level. The highest correlations were found between the scales of Policy and Prevention, Organisational Strategies and Promote Good working Relationships.

Table 2. Correlations between the Scales of the Study $(\mathrm{N}=317)$

\begin{tabular}{|c|c|c|c|c|c|c|}
\hline & & 1 & 2 & 3 & 4 & 5 \\
\hline 1 & Policy and Prevention & & & & & \\
\hline 2 & Creating Awareness & $.85^{* * *}$ & & & & \\
\hline 3 & $\begin{array}{l}\text { Promote Good Working } \\
\text { Relationships }\end{array}$ & $.80 * * *$ & $.64 * * *$ & & & \\
\hline 4 & $\begin{array}{l}\text { Organisational } \\
\text { Strategies }\end{array}$ & $.90 * * *$ & $.80 * * *$ & $.90 * * *$ & & \\
\hline 5 & $\begin{array}{l}\text { Support Recovery at } \\
\text { Work }\end{array}$ & $.81 * * *$ & $.70 * * *$ & $.70 * * *$ & $.81 * * *$ & \\
\hline 6 & $\begin{array}{l}\text { Evaluation of } \\
\text { Policy/Action Plan }\end{array}$ & $.83^{* * *}$ & $.70 * * *$ & $.70 * * *$ & $.81 * * *$ & $.74 * * *$ \\
\hline
\end{tabular}

In Table 3 overall mean values of the responses on all six scales are presented which were between 1.34 to 2.1, that is between 1 (Disagree) to 2 (Neutral). Consequently, the results of descriptive statistics show that not enough efforts have been made by the university administration for all six categories/scales considered to design the framework to reduce occupational stress. Only one significant difference was found on the scale to Promote Good Working Relationships; female university teachers were more inclined to promote good working relationships as compared to male teachers with $\mathrm{MD}=$ $.26, \mathrm{SD}=.92, \mathrm{p}<.02$. Each subscale is further elaborated below in the discussion.

Table 3. Descriptive Statistics and Mean Differences Between Males $(\mathrm{n}=175)$ and Females $(\mathrm{n}=142)$

\begin{tabular}{llll}
\hline & \multicolumn{2}{c}{ Mean (SD) } & $p$ \\
\hline & Male (176) & Female (144) & \\
Policy and Prevention & $1.50(.96)$ & $1.60(.92)$ & .35 \\
Creating Awareness & $1.34(1.03)$ & $1.33(.92)$ & .90 \\
$\begin{array}{l}\text { Promote Good Working } \\
\text { Relationships }\end{array}$ & $1.94(1.05)$ & $2.20(.92)$ & .02 \\
$\begin{array}{l}\text { Organizational } \\
\text { Strategies }\end{array}$ & $1.78(1.00)$ & $2.0(.91)$ & .11 \\
$\begin{array}{l}\text { Support recovery at } \\
\text { work }\end{array}$ & $1.32(1.06)$ & $1.50(.98)$ & .22 \\
$\begin{array}{l}\text { Evaluation of } \\
\text { Policy/Action Plan }\end{array}$ & & & \\
\hline
\end{tabular}

\section{Gender Differences}

To examine gender differences, a multivariate analysis of variance (MANOVA) was conducted with gender as an independent variable and the six scales as dependent variables. The multivariate analysis was not significant for gender (Table 4). The univariate analyses showed no significant difference in the responses of both male and female teachers on the five scales of the study. There was only one significant gender difference on the scale of Promote Good Working Relationships with females scoring higher than males. 
Table 4.

Results of a Multivariate Analysis of Variance (MANOVA) with Gender as Independent Variable and the Six Scales of the Study as Dependent Variables $(\mathrm{N}=320)$.

\begin{tabular}{|c|c|c|c|c|c|}
\hline & $F$ & $d f$ & $p \leq$ & $\eta_{\mathrm{p}}^{2}$ & $\begin{array}{c}\text { Group } \\
\text { differences }\end{array}$ \\
\hline \multicolumn{6}{|l|}{ Effect of Gender } \\
\hline Multivariate Analysis & 1.646 & 6,310 & $n s$ & .031 & \\
\hline \multicolumn{6}{|l|}{ Univariate Analyses } \\
\hline Policy and Prevention & .874 & 1,315 & $n s$ & .003 & $n s$ \\
\hline Creating Awareness & .016 & “ & $n s$ & .000 & $n s$ \\
\hline $\begin{array}{l}\text { Promote Good Working } \\
\text { Relationships }\end{array}$ & 5.172 & " & .024 & .016 & Female $>$ Male \\
\hline Organisational Strategies & 2.591 & “ & $n s$ & .008 & $n s$ \\
\hline Support Recovery at Work & 1.492 & $"$ & $n s$ & .005 & $n s$ \\
\hline $\begin{array}{l}\text { Evaluation of Policy/Action } \\
\text { Plan }\end{array}$ & 1.189 & “ & $n s$ & .004 & $n s$ \\
\hline
\end{tabular}

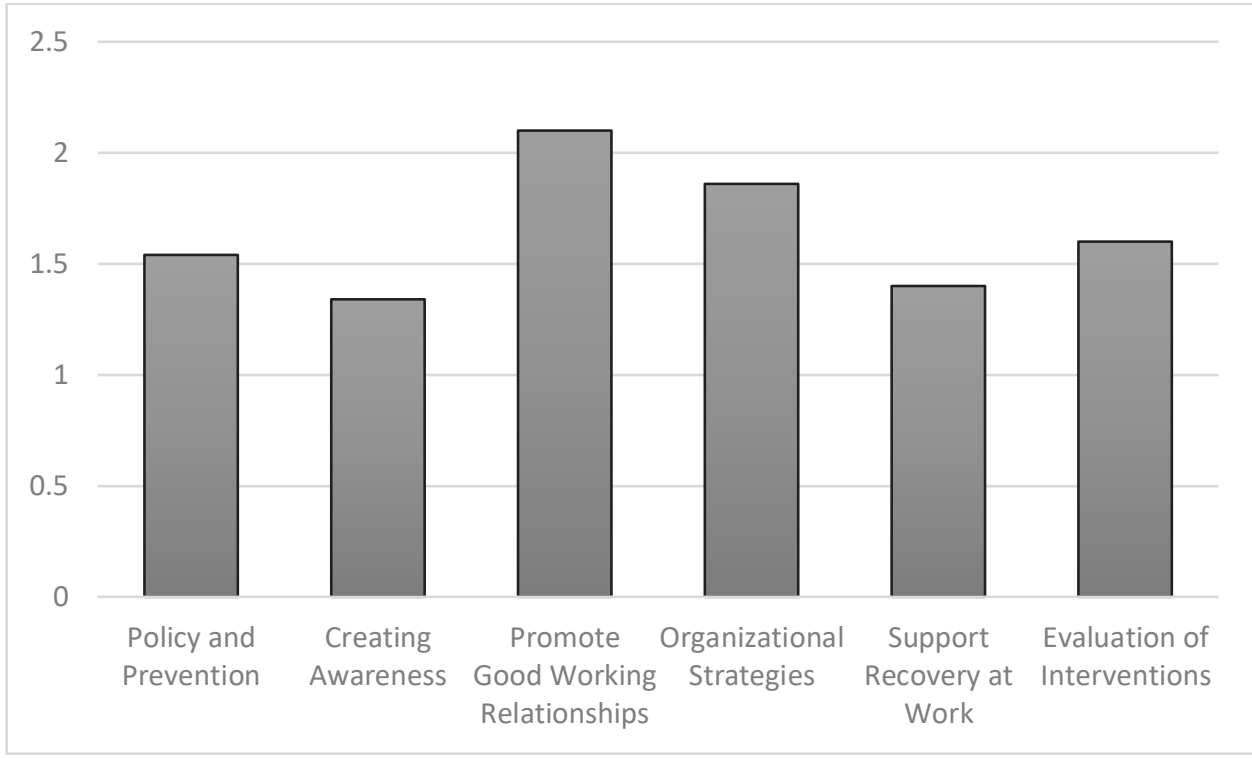

Figure 1. Overall mean scores of respondents from Pakistan on the six scales of the study $(N=320)$.

\section{Discussion}

The questionnaire, with its six subscales, was designed to investigate the efforts and strategies of university administrations to design and implement a policy to deal with the issues of stress and burnout in university settings. The findings demonstrate that university teachers believe that not enough is being done by the university administration to address these issues. Thus, a policy/action plan and effective interventions are needed to lower job stress and burnout in order to improve the university work environment for the teachers.

In light of the results of this study, the following framework/guideline is suggested for university administrations to deal with occupational stress and burnout among teachers.

\section{a) Policies / Action Plan Implementation}

The results regarding this scale reveal that the mean score for male teachers was 1.50 and for females 1.60. By keeping the results in view, it can be assumed that Pakistani universities do not seem to have any policy or action plan aiming at resolving the problem of occupational stress and burnout 
among university teachers. Thus, university administrations should try to identify the stressors in the work environment and design a policy and action plan to reduce stress among employees and provide a solution to this issue (Yusoff, \& Khan, 2013; Khan et al., 2014). Actions to reduce occupational stress should be decided beforehand by identifying the possible solutions to the causes of occupational stress. Before implementing the plan, the procedure for implementation should also be decided (Houtman, Jettinghof, \& Cedillo, 2007). Participation of teachers in the planning process is essential, as they understand their work environment best and therefore may have valuable ideas about how to improve it. As a general rule, the head of the department and teachers' representatives must be aware of signs and symptoms of work-related stress, and they should be best equipped to manage job stress and make necessary structural changes before it becomes a serious problem for the teaching staff. The evidence of signs and symptoms among teachers should also be gathered on a periodic basis. The implementation of a policy/action plan should be ensured, and before the implementation, financial cost and advantages of the plan should be assessed.

\section{b) Create Awareness among Stakeholders}

The mean score on this scale was 1.34 for male university teachers, and 1.33 for female teachers. These are the lowest means as compared to the mean scores of the other five scales of the study. This finding explains that the situation is not good concerning the creating of awareness about stress and burnout among teachers in the higher educational institutions in Pakistan. Keeping the results in mind, it can be said that very little is being done in Pakistani universities to create awareness about the problem. This could be corrected with the provision of written and verbal information or by arranging workshops, training sessions, and seminars for the staff (Houtman, et al., 2007; Vasumathi, 2010). The support of family and colleagues is vital to decrease the negative consequences of stress. Therefore, family members could be included in the awareness campaign. Special stress management skills, including strategies for disengagement from work at home, could be in focus for the awareness campaign.

To identify teachers at risk, data should preferably be collected using several methods, such as questionnaires, checklists, interviews, and by analysing teachers' patterns of absence (Houtman, et al., 2007). This information should be made available to the teachers themselves, not only to the administration so that all the university employees will become aware of whether they are at risk for suffering burnout from their stress. Teachers' involvement in the stress management process is crucial.

\section{c) Promote Good Working Relationships}

The mean score on this scale was 1.9 for males and 2.2 for females. There is room for improvement of the working relationships at Pakistani universities. As good working relationships and social support among colleagues are very important for the harmonious work environment, training courses should be offered to the head of the departments and the staff on stress management and how to lead in a stress-reducing way (Houtman, et al., 2007). Also, different opportunities should be provided for the teachers to discuss, share, understand, and support their colleagues in different situations in the daily work environment. Policymakers should design adaptive and accommodating social support systems (Gubbins, Harrington, \& Hines, 2020). Poor relationships with colleagues increase the level of stress (Boyle, Borg, Falzon, \& Baglioni, 1995). Research has established that colleague support acts as a resource for teachers and has a positive effect on their performance (Wolgast \& Fischer, 2017) and it is linked to positive outcomes (Lambert, Minor, Wells, \& Hogan, 2016). If stressful relationships are left unchecked, it will generate a negative work climate which in turn affect others who are part of the community (Cohen, McCabe, Michelli, \& Pickeral, 2009).

Thus, in order to develop good working relationships, it is suggested that possibilities for regular face to face communication should be ensured, as lack of communication is a key stressor in itself (Czech \& Forward, 2010; Mark \& Smith, 2018). Maintaining open communication between teachers and administrators to provide performance feedback and support may act as a buffer against stress (Vasumathi, 2010). Informal communication could be useful not only for dealing with existing stressors but could also anticipate potential problems (Mark \& Smith, 2018). This can be arranged 
through different social activities for the teaching staff. They may have coffee/tea breaks or lunch/dinners together so that they could share their ideas with rest of the colleagues in a free and informal environment and communication and knowledge sharing among colleagues and head of the department should be improved. Possibilities for recreational activities are also essential to keep teachers motivated, and it can also foster friendship among them (Carls, 2020).

\section{d) Organisational Strategies}

The results regarding this scale showed that the mean score for males was 1.782 .0 for females. Thus, it appears that during and after the planning of organisational strategies, it is necessary to share them with the staff as they are the stakeholders, and they can sometimes provide feedback concerning the planned strategies. It should be discussed with them how the plan could be best implemented to reduce possible resistance, which otherwise could take place during the process of implementation. Teachers should also be part of decision making. Training sessions for stress management practices can be combined with a continuous professional development plan to help teachers to understand and manage stressful situations (Vasumathi, 2010). For this, workshops, seminars, and short-term in-service training by professionals in the area should be provided. It is needed to make the teachers develop better emotional control by introducing them with useful stress management skills (Kyriacou, 2001). Regular meetings should be arranged to discuss the problems faced by the teachers and find solutions collectively. A trustworthy environment should be developed by promoting knowledge sharing, social support, and cooperation between colleagues and the head of the department (Al-Kurdi, El-Haddadeh, \& Eldabi, 2020). Team spirit should be developed among the teachers by organising different group activities. Clear rules and regulations regarding development opportunities, evaluation, and promotion criteria should be laid out. Intra-organisational communication should be improved, including feedback, encouraging openness and developing a shared vision.

Work should be distributed equally among teachers, and for certain stressful tasks, a rotation plan could be made. Clear job duties should be described. Redistribution of responsibilities among teachers should be introduced so that every teacher could get a chance to experience different situations. This will provide them with the opportunity to understand the different nature of the jobs, and it could also increase empathy for others, and they work. University administrations should improve working conditions, and all the necessary facilities should be provided to improve the performance of the teachers (Malik, Björkqvist, \& Österman, 2017a; Malik, Björkqvist, \& Österman, 2017b).

\section{e) Support Recovery at Work}

The results showed that the mean score on this scale was 1.32 for males and 1.50 for females. It suggests that universities need to introduce counselling and mentoring programs to address jobrelated matters. These programs should use awareness-raising activities, stress management education, and knowledge and skills training (Bhagat, Segovis, \& Nelson, 2012). There is significant research indicating the advantage of professional development approaches based upon support and guidance from a mentor (Desimone et al., 2014) or coach (Bull \& Buechler, 1995; Nishimura, 2014). If such opportunities are made available to the teachers, they may consider it as support and concern shown by their administration. They feel more satisfied with their job and consider their organisation more supportive (Siu, Cooper, \& Phillips, 2014). A study by Griffith, Steptoe, and Cropley (1999) shows that both the use of effective coping strategies and social support can influence the teacher's experience of stress.

In this study, most teachers expressed that there are scarce opportunities for any support systems or counselling available for stress-related issues. Therefore, it is suggested that mentors should be provided at work, and professional help from a psychologist and occupational health services should be available to the teachers to get help whenever needed. Provision of reward, acknowledgement, and support from co-workers and the head of the department should be ensured to the teachers. It is essential to develop an environment of trust and respect to make the teachers feel safe, satisfied, and enjoy their work. 


\section{f) Evaluation of Policy/Action Plan}

Evaluation is important to make further changes and improve policies. The mean score of the responses on this scale was 1.61 for males and 1.73 for females, which shows that a majority of the teachers believed that not much effort had been made by the administration for evaluation of any policy regarding occupational stress and burnout if there even was one to begin with. To judge whether the plan has been successfully implemented and the desired results have been produced, there are some points to be considered. First, it is important to evaluate to what extent the goals have been achieved. Second, the financial cost and effectiveness of the plan should be assessed. Third, are the teachers satisfied with the arrangements and the ways of implementation? Fourth, in order to assess and compare the changes which took place by implementing the policy/action plan, the teachers should be asked to analyse the present situation and compare it with how it was before (Houtman, et al., 2007). Such information could be collected by analysing results from questionnaires, interviews, checklists, discussion, and observations.

\section{Limitations of the Study}

This study has several limitations that should be mentioned. The first limitation was the representativeness of the sample. Even though an attempt was made to collect data from different regions of Pakistan, it cannot be claimed that the sample is fully representative. Moreover, the estimation of an exact response rate is not possible, as it is hard to establish the exact number of valid email addresses to which the electronic questionnaire was sent. Second, it may be argued that a paperand-pencil questionnaire may have shown dissimilar results than an electronic one. However, Boyer, Olson, Calantone, and Jackson (2002) found that e-surveys are equally good as manual surveys: both techniques have similar response rates and obtain more or less similar results. Third, the sample comprised of university teachers, and results may not be generalised to other professions as the level of occupational stress and burnout may vary between professions. Generalisations to other professions and other countries must be made carefully until a similar study has been replicated in their context.

\section{Conclusion}

Previous research has established that university teachers in Pakistan are seriously suffering from occupational stress and burnout (Faisal, Noor, \& Khair, 2019; Khan, Din, \& Anwar, 2019; Malik, Björkqvist, \& Österman, 2017a; Malik, Björkqvist, \& Österman, 2017b; Malik \& Björkqvist, 2019). Previous studies highlight the need to develop policy frameworks to deal with this emerging issue before it damages the physical and mental health of increasing numbers of teachers (Arshad, 2019; Khan, et al., 2019; Malik \& Björkqvist, 2018).

This study has intended to fill this gap and provide a suggestion for guidelines for university administrations, to help them design a policy framework for the management of occupational stress and burnout among university teachers in Pakistan. This framework may also be useful for university administrations in other countries.

Results of this study support the idea that in higher education institutions, professional development activities related to creating awareness about occupational stress, burnout, and stress management skills should be encouraged. Universities must consider the prevention of work stress a priority and develop a policy framework to counter it. The administration should implement different strategies and offer training sessions on a regular basis to the teachers, to enhance their stress management skills so that they perceive their jobs as less stressful. The administration should design policies and allow teachers to participate in policymaking. However, there are many challenges to face during this process as it requires resources, the support of top management, and incorporating the programs into the overall programme of the organisation. But if we ignore the warning signs of occupational stress among university teachers, they can lead to major problems and affect their wellbeing. There is a need to adopt positive ways to maintain feelings of happiness and help teachers and their organisations to effectively cope with occupational stress. 


\section{References}

Agatha, L.M. \& Chan, Y.F. (2020). Psychological empowerment and organisational commitment among academic staff of public universities in Malaysia. Asian Journal of University Education, 16(2), 26-35

Al-Kurdi, O. F., El-Haddadeh, R., \& Eldabi, T. (2020). The role of organisational climate in managing knowledge sharing among academics in higher education. International Journal of Information Management, 50, 217-227.

Arshad, M. (2019). Professional life stressors among teaching faculty at tertiary level. UMT Education Review (UER), 2, 27-46.

Bermejo-Toro, L. \& Prieto-Ursúa, M. (2014). Absenteeism, burnout and symptomatology of teacher stress: sex differences. International Journal of Educational Psychology, 3, 175-201. doi:10.4471/ijep.2014.10

Bhagat, R. S., Segovis, J. C., \& Nelson, T. A. (2012). Work stress and coping in the era of globalisation. New York: Routledge.

Bhatti, N., Hashmi, M. A., Raza, S. A., Shaikh, F. M., \& Shafiq, K. (2011). Empirical analysis of job stress on job satisfaction among university teachers in Pakistan. International Business Research, 4, 264-270.

Brotman, D. J., Golden, S. H., \& Wittstein, I. S. (2007). The cardiovascular toll of stress. The Lancet, $370,1089-1100$.

Brown, Z. A., \& Uehara, D. L. (1999). Coping with teacher stress: A research synthesis for Pacific educators. Honolulu, HI: Pacific Resources for Education and Learning.

Bull, B. \& Buechler, M. (1995). Time for professional development: Ideas for Indiana. (Policy Bulletin No. PB-B24). http://files.eric.ed.gov/fulltext/ED381888.pdf

Bunce, D., \& West, M. A. (1996). Stress management and innovation interventions at work. Human Relations, 49, 209-232.

Boyle, G. J., Borg, M. G., Falzon, J. M., \& Baglioni Jr, A. J. (1995). A structural model of the dimensions of teacher stress. British Journal of Educational Psychology, 65, 49-67.

Carls, K. M. (2020). What motivates teachers to stay faithful to the teaching profession? International Multidisciplinary Research Journal, 10, 22-34.

Cohen, J., McCabe, E., Michelli, N., \& Pickeral, T. (2009). School climate: Research, policy, practice, and teacher education. Teachers College Record, 111, 180-213.

Collie, R. J., Shapka, J. D., \& Perry, N. E. (2012). School climate and social-emotional learning: Predicting teacher stress, job satisfaction, and teaching efficacy. Journal of Educational Psychology, 104, 1189-1204. doi:10.1037/a0029356

Correnti, R. (2007). An empirical investigation of professional development effects on literacy instruction using daily logs. Educational Evaluation and Policy Analysis, 29, 262-295.

Czech, K., \& Forward, G. L. (2010). Leader communication: Faculty perceptions of the department chair. Communication Quarterly, 58, 431-457.

Desimone, L. M., Porter, A. C., Garet, M. S., Yoon, K. S., \& Birman, B. F. (2002). Effects of professional development on teachers' instruction: Results from a three-year longitudinal study. Educational Evaluation and Policy Analysis, 24, 81-112.

Desimone, L. M., Hochberg, E. D., Porter, A. C., Polikoff, M. S., Schwartz, R., \& Johnson, L. J. (2014). Formal and informal mentoring: Complementary, compensatory, or consistent? Journal of Teacher Education, 65, 88-110.

Dimsdale, J. E. (2008). Psychological stress and cardiovascular disease. Journal of the American College of Cardiology, 51, 1237-1246. doi:10.1016/ j. jacc.2007.12.024

Donovan, R. A. (2018). Perceptions of stress, workload, and job satisfaction among HSS Faculty: Executive summary. Kennesaw, GA: Kennesaw State University.

Faisal, F., Noor, N., \& Khair, A. (2019). Causes and consequences of workplace stress among Pakistan university teachers. Bulletin of Education and Research, 41, 45-60.

Ganster, D. C., Mayes, B. T., Sime, W. E., \& Tharp, G. D. (1982). Managing organisational stress: A field experiment. Journal of Applied Psychology, 67, 533-542. 
Garet, M. S., Porter, A. C., Desimone, L., Birman, B. F., \& Yoon, K. S. (2001). What makes professional development effective? Results from a national sample of teachers. American Educational Research Journal, 38, 915-945.

Gershon, R., Barocas, B., Canton, A., Li, X., \& Vlahov, D. (2009). Mental, physical, and behavioral outcomes associated with perceived work stress in police officers. Criminal Justice and Behavior, 36, 275-289. doi:10.1177/0093854808330015

Giga, S. I., Cooper, C. L., \& Faragher, B. (2003). The development of a framework for a comprehensive approach to stress management interventions at work. International Journal of Stress Management, 10, 280-296. doi:10.1037/1072-5245.10.4.280

Griffith, J., Steptoe, A., \& Cropley, M. (1999). An investigation of coping strategies associated with job stress in teachers. British Journal of Educational Psychology, 69, 517-531.

Gubbins, M., Harrington, D., \& Hines, P. (2020). Social support for academic entrepreneurship: definition and conceptual framework. Journal of Management Development, 39. doi:10.1108/JMD-11-2019-0456

Hartney, E. (2008). Stress management for teachers. London, UK: Continuum International Publishing Group.

Hartney, E. (2020). Stress management to enhance teaching quality and teaching effectiveness: A professional development framework for teachers. In Information Resources Management Association (IRMA), Occupational stress: Breakthroughs in research and practice (pp. 306331). IGI Global. doi: 10.4018/978-1-7998-0954-8.ch014

Heaney, C. A., \& Van Ryn, M. (1990). Broadening the scope of worksite stress programs: A guiding framework. American Journal of Health Promotion, 4, 413-420.

Houtman, I., Jettinghof, K., \& Cedillo, L. (2007). Raising awareness of stress at work in developing countires: a modern hazard in a traditional working environment: advice to employers and worker representatives. World Health Organization (WHO).

Ivancevich, J. M., Matteson, M. T., Freedman, S. M., \& Phillips, J. S. (1990). Worksite stress management interventions. American Psychologist, 45, 252-261. doi:10.1037/0003-066X.45.2.252

Jepson, E., \& Forrest, S. (2006). Individual contributory factors in teacher stress: The role of achievement striving and occupational commitment. British Journal of Educational Psychology, 76, 183-197. doi:10.1348/000709905X37299

Johnsrud, L. K. (2002). Measuring the quality of faculty and administrative work life: Implications for college and university campuses. Research in Higher Education, 43, 379-395.

Kerr, R., Breen, J., Delaney, M., Kelly, C., \& Miller, K. (2011). A qualitative study of workplace stress and coping in secondary teachers in Ireland. Irish Journal of Applied Social Studies, 11, 26-38.

Khan, F., Rasli, A. M., Khan, S., Yasir, M., \& Malik, M. F. (2014). Job burnout and professional development among universities academicians. Science International Lahore, 26, 1693-1696.

Khan, A., Din, S.U; Anwar, M. (2019). Sources and adverse effects of burnout among academic staff: A systematic review. City University Research Journal, 9, 350-363.

Kinman, G., \& Wray, S. (2013). Stressed out: The report of a survey into occupational stress in adult education University and College Union UK. https://docplayer.net/19380561-Stressed-out-thereport-of-a-survey-into-occupational-stress-in-adult-education.html

Kortum, E., Leka, S., \& Cox, T. (2010). Psychosocial risks and work-related stress in developing countries: Health impact, priorities, barriers and solutions. International Journal of Occupational Medicine and Environmental Health, 23, 225-238. doi:10.2478/v10001-010-0024-5

Kyriacou, C. (2001). Teacher stress: Directions for future research. Educational Review, 53, 27-35.

Kyriacou, C., \& Sutcliffe, J. (1977). Teacher stress: A review. Educational Review, 29, 299-306.

Lambert, E. G., Minor, K. I., Wells, J. B., \& Hogan, N. L. (2016). Social support's relationship to correctional staff job stress, job involvement, job satisfaction, and organisational commitment. Social Science Journal, 53, 22-32.

Malik, N. A., Björkqvist, K., \& Österman, K. (2017a). Factors associated with occupational stress among university teachers in Pakistan and Finland. Journal of Educational, Health and Community Psychology, 6, 1-14. 
Malik, N. A., Björkqvist, K., \& Österman, K. (2017b). Sick-leave due to burnout among university teachers in Pakistan and Finland and its psychosocial concomitants. European Journal of Social Sciences Education and Research, 10, 203-212.

Malik, N. A., \& Björkqvist, K. (2018). Occupational stress and mental and musculoskeletal health among university teachers. Eurasian Journal of Medical Investigation, 2, 139-147.

Malik, N. A., \& Björkqvist, K. (2019). Workplace bullying and occupational stress among university teachers: Mediating and moderating factors. Europe's Journal of Psychology, 15, 240-259.

Mark, G., \& Smith, A. (2018). A qualitative study of stress in university staff. Advances in Social Sciences Research Journal, 5, 238-247. doi:10.14738/assrj.52.4195.

Mohammed, S. S., Suleyman, C., \& Taylan, B. (2020). Burnout determinants and consequences among university lecturers. Amazonia Investiga, 9, 13-24.

Mostert, F. F., Nell, K., Mostert, K., \& Rothmann, S. (2008). Outcomes of occupational stress in a higher education institution. Southern African Business Review, 12, 102-127.

Naghieh, A., Montgomery P., Bonell, C. P., Thompson, M., Aber, J. L. (2015). Organisational interventions for improving wellbeing and reducing work-related stress in teachers. Cochrane Database of Systematic Reviews, Issue 4. Art. No.: CD010306. doi:10.1002/14651858.CD010306.pub2.

Narayanappa, S., Manjunath, R., \& Kulkarni, P. (2016). Mental health risk factors influencing metabolic syndrome among secondary school teachers of Mysore city. International Journal of Community Medicine and Public Health, 3, 998-1009. doi:10.18203/23946040.ijcmph20160978

Navarro, M. L. A., Mas, M. B., \& Jimenez, A. M. L. (2010). Working conditions, burnout and stress symptoms in university professors: Validating a structural model of the mediating effect of perceived personal competence. Spanish Journal of Psychology, 13, 284-296. doi:10.1017/ S1138741600003863

Navinés, R., Martin-Santos, R., Olive, V., \& Valdes, M. (2016). Work-related stress: Implications for physical and mental health. Medicina Clinica, 146, 359-366. doi: 10.1016/j.medcli.2015.11.023

Nishimura, T. (2014). Effective professional development of teachers: A guide to actualising inclusive schooling. International Journal of Whole Schooling, 10, 19-42.

Nixon, A. E., Mazzola, J. J., Bauer, J., Krueger, J. R., \& Spector, P. E. (2011). Can work make you sick? A meta-analysis of the relationships between job stressors and physical symptoms. Work \& Stress, 25, 1-22.

Olkinuora, M., Asp, S., Juntunen, J., Kauttu, K., Strid, L., \& Äärimaa, M. (1990). Stress symptoms, burnout and suicidal thoughts in Finnish physicians. Social Psychiatry and Psychiatric Epidemiology, 25, 81-86.

Otero-López, J. M., Santiago Mariño, M. J., \& Castro Bolaño, C. (2008). An integrating approach to the study of burnout in university professors. Psicothema, 20, 766-772.

Raza, A. (2012). Relationship between occupational stress and job satisfaction of faculty: The case of universities of Punjab. Human Resource Management, Elixir, 43, 6913-6920.

Richardson, K. M., \& Rothstein, H. R. (2008). Effects of occupational stress management intervention programs: A meta-analysis. Journal of Occupational Health Psychology, 13, 69-

93. doi:10.1037/1076-8998.13.1.69

Schaufeli, W., \& Buunk, B. P. (2003). Burnout: An overview of 25 years of research and theorising. In M. J. Schabracq, J. A. M. Winnubst, \& C. L. Cooper (Eds.), Handbook of work and health psychology (pp. 383-425). Chichester: Wiley.

Siu, O. L., Cooper, C. L., \& Phillips, D. R. (2014). Intervention studies on enhancing work wellbeing, reducing burnout, and improving recovery experiences among Hong Kong health care workers and teachers. International Journal of Stress Management, 21, 69-84.

Skaalvik, E .M., Skaalvik, S. (2017) .Teacher stress and teacher self-efficacy: Relations and consequences. In T. McIntyre, S. McIntyre, \& D. Francis (Eds.) Educator stress. Aligning perspectives on health, safety and wellbeing. (pp. 101-125). Springer: Cham.

Slišković, A., \& Seršić, D. (2011). Work stress among university teachers: Gender and position differences. Archives of Industrial Hygiene and Toxicology, 62, 299-307. 
Steinhardt, M., Jaggars, S., Faulk, K., \& Gloria, C. (2011). Chronic work stress and depressive symptoms: Assessing the mediating role of teacher burnout. Stress \& Health, 27, 420-429. doi: $10.1002 / \mathrm{smi} .1394$

Takahashi, A. N. (2016). Job stress in Japanese academia: The role of relative income, time allocation by task, and children. Journal of Asian Economics, 43, 12-17. doi:10.1016/j.asieco. 2016.01.004

Tucker, S. (2010). An investigation of the stresses, pressures and challenges faced by primary school head teachers in a context of organisational change in schools. Journal of Social Work Practice, 24, 63-74. doi:10.1080/02650530903532765

Vasumathi, T. (2010). A design for professional development of teachers need for new policy framework. http://www.eric.ed.gov/contentdelivery/servlet/ ERICServlet?accnoDED512828

Wang, J., Lesage, A., Schmitz, N., \& Drapeau, A. (2008). The relationship between work stress and mental disorders in men and women: findings from a population-based study. Journal of Epidemiology \& Community Health, 62, 42-47.

Watts, J., \& Robertson, N. (2011). Burnout in university teaching staff: A systematic literature review. Educational Research, 53, 33-50.

Wellen, K. E., \& Hotamisligil, G. S. (2005). Inflammation, stress, and diabetes. Journal of Clinical Investigation, 115, 1111-1119.

Williams, S., \& Cooper, C. L. (1998). Measuring occupational stress: Development of the pressure management indicator. Journal of Occupational Health Psychology, 3, 306-321. doi:10.1037/1076-8998.3.4.306

Winefield, A. H., Gillespie, N., Stough, C., Dua, J., Hapuarachchi, J., \& Boyd, C. (2003). Occupational stress in Australian university staff: Results from a national survey. International Journal of Stress Management, 10, 51-63. doi:10.1037/1072-5245.10.1.51

Wolgast, A., \& Fischer, N. (2017). You are not alone: Colleague support and goal-oriented cooperation as resources to reduce teachers' stress. Social Psychology of Education, 20, 97-114.

Yu, X., Wang, P., Zhai, X., Dai, H., \& Yang, Q. (2015). The effect of work stress on job burnout among teachers: The mediating role of self-efficacy. Social Indicators Research, 122, 701--708.

Yusoff, R. M., \& Khan, F. (2013). Stress and burnout in the higher education sector in Pakistan: A systematic review of literature. Research Journal of Recent Sciences, 2, 90-98.

Zhao, X., \& Ding, S. (2020). Phenomenology of burnout syndrome and connection thereof with coping strategies and defense mechanisms among university professors. European Journal of Investigation in Health, Psychology and Education, 10, 82-93. 